\title{
PERLINDUNGAN HUKUM TERHADAP JUSTICE COLLABORATOR TERKAIT PENANGANAN TINDAK PIDANA KORUPSI DI INDONESIA
}

\author{
Oleh: \\ Rika Ekayanti ${ }^{1}$
}

\begin{abstract}
The discussion in this thesis raised regarding Legal Protection against Justice Collaborator in the handling of corruption in Indonesia. The objectives of this study are to be analyzed with both forms of regulation and identify the type of protection provided by the laws of the State of Indonesia justice collaborator and determine the accuracy of the strength of the evidential value of the testimony in the trial of a justice collaborator, by analyzing the legal provisions in the legislation other law relating to witnesses. This type of research is used in a scientific journal this is the kind of normative legal research, because there is disharmony norm based research in the form of a legal vacuum regarding the setting justice collaborator in formal laws and regulations in Indonesia, as well as the legal ambiguities in the text of the legislation on Article 10 paragraph (2) Law No.. 13 of 2006 on the Protection of Witnesses and Victims of the justice collaborator testimony that can be used as consideration to give the judge for leniency. Having regard to the development of the current law that requires courage and willingness of law enforcement in combating corruption as an extraordinary crime, it is necessary to break the law through the use of an instrument justice collaborator.
\end{abstract}

Keywords: Protection Law, Justice Collaborator, and Corruption

\section{PENDAHULUAN}

\subsection{Latar Belakang}

Korupsi masih merupakan permasalahan serius yang dialami oleh Negara berkembang termasuk Indonesia, korupsi sudah merebak di segala bidang dan sektor kehidupan masyarakat secara meluas, sistematis dan terorganisir dengan akibat pada timbulnya krisis ekonomi, rusaknya

Mahasiswa MagisterIlmuHukumUniversitas Udayana, Denpasar,Bali. Alamat Jl. Jl. By pass Ngurah Rai, No. 11A Tuban Kuta Bali , e-mail : rikaekayanti@gmail. com sistem hukum dan menghambat jalannya pemerintahan yang bersih dan demokratis.

Penjelasan UU RI No. 20 Tahun 2001 tentang Perubahan Atas UU RI No. 31 Tahun 1999 tentang Pemberantasan Tindak Pidana Korupsi dan Penjelasan UU RI No. 30 Tahun 2002 tentang Komisi Pemberantasan Tindak Pidana Korupsi telah menyatakan korupsi sebagai kejahatan luar biasa (extraordinary crime) sehingga pemberantasannya juga diperlukan usaha yang luar biasa, salah satunya melalui terobosan hukum dengan penggunaan instrument justice collaborator. 
Peran justice collaborator atau saksi pelaku yang bekerjasama, menurut Fausto Zuccarelli diawali dengan munculnya "pentiti" (mafia yang bertobat) pada Tahun 1930-an di Italia, KUHP Italia saat itu mengatur adanya kekebalan dari hukuman jika pelaku memperbaiki kerusakan yang diakibatkan perbuatan pidananya melalui bekerjasama dengan pihak berwenang dalam kasus-kasus konspirasi politik atau yang berhubungan dengan kegiatan gangster. ${ }^{2}$

Perkembangannya kemudian Negara seperti Amerika Serikat, Australia, Belanda, dan Albania memberikan perhatian akan pentingnya perlindungan saksi whistle blower dan justice collaborator guna memperoleh kesaksian yang akan mengungkap kejahatan secara tuntas, dengan mengakomodir aturan perlindungan whistle blower dan justice collaborator yang komprehensif dalam suatu bentuk peraturan perundang-undangan formil yakni Undang-Undang.

Fenomena justice collaborator di Indonesia mulanya mengemuka dari peran Agus Condro Prayitno mengungkap kasus traveler cheque pemilihan Deputi Senior Gubernur Bank Indonesia, Miranda Swaray Gultom yang melibatkan 31 Anggota Komisi IX DPR Periode 1999-2004, penetapan Agus C. Prayitno sebagai justice collaborator oleh KPK didasari pertimbangan dalam Peraturan Bersama Tahun 2011 dan SEMA No. 4 Tahun

Fausto Zuccarelli, 2011, Vice Chief Prosecutor's Office attached to the court of Naples, Italy, Handling and Protecting Witnesses and Collaborators of Justice in Italy, International Seminar and Focus Group Discussion The Protection of Whistleblowers as Justice collaborators, Jakarta, July 19-20 ${ }^{\text {th. }}$
2011, sebagai berikut : Pertama, Perannya sebagai pelaku korupsi bekerjasama memberikan informasi yang faktual, terbukti dari kesaksiannya yang dipergunakan sebagai alat bukti oleh Pengadilan Tindak Pidana Korupsi; Kedua, Kooperatif dalam menjalani seluruh proses penegakan hukum kasusnya, serta tidak pernah melarikan diri; Ketiga, Mengaku dengan tegas telah melakukan korupsi; dan Keempat, Statusnya sebagai justice collaborator secara resmi diakui eksistensinya oleh Lembaga Perlindungan Saksi dan Korban. Reward yang diterima oleh Agus C. Prayitno kemudian adalah KPK memberikan tuntutan terendah diantara para terdakwa, Hakim memberikan vonis teringan, Kementerian Hukum dan HAM memindahkan Agus C. Prayitno ke Lembaga Pemasyarakatan yang berlokasi didekat rumah tempat tinggalnya, serta memberikan semua hak pengurangan hukumannya termasukasimilasidanpembebasanbersyarat. Pada kasus berikutnya justice collaborator seperti Mindo Rosalina Manulang, Sukotjo Bambang telah diberikan penghargaan pada Tahun 2012 berupa remisi tambahan dan pembebasan bersyarat. Tahun 2013 Kosasih Abbas, terpidana kasus korupsi Solar Home System di Kementerian Energi dan Sumber Daya Mineral telah meraih penghargaan pertama Senarai justice collaborator disusul Vincentius Amin Sutanto terpidana kasus penggelapan pajak mendapat penghargaan serupa, sehingga keduanya menerima pembebasan bersyarat. Lebih lanjut, Hakim Agung Dr. Artidjo Alkostar, Prof. Dr. Surya Djaya, dan Sri Murwahyuni dalam 
Putusan bernomor No. 920K/Pid.Sus/2013, menjatuhkan vonis ringan bagi Thomas Claudius Ali Junaidi, justice collaborator dalam kasus Narkotika. Dengan demikian sesungguhnya pengaturan justice collaborator mulai diterima dalam praktik hukum pidana Indonesia, meskipun tidak memiliki payung hukum yang tegas sehingga dikhawatirkan akan menimbulkan disparitas bagi penerapan hukum kedepannya.

Pengaturan mengenai justice collaborator selama ini diatur secara bervariasi, limitatif dan tersebar diberbagai ketentuan perundang-undangan. Pasal 10 ayat (2) UU RI No. 13 Tahun 2006 tentang Perlindungan Saksi dan Korban (UU PSK), merupakan landasan penggunaan peran justice collaborator di Indonesia secara limitatif, yang berbunyi :

“(2) Seorang saksi yang juga tersangka dalam kasus yang sama tidak dapat dibebaskan dari tuntutan pidana apabila ia ternyata terbukti secara sah dan meyakinkan bersalah, tetapi kesaksiannya dapat dijadikan pertimbangan hakim dalam meringankan pidana."

Pengaturan justice collaborator yang lebih komprehensif justru terdapat dalam Surat Edaran Mahkamah Agung No. 4 Tahun 2011 tentang Perlakuan bagi Pelapor Tindak Pidana (Whistleblower) dan Saksi Pelaku yang Bekerjasama (Justice Collaborator) didalam Perkara Tindak Pidana Tertentu tanggal 10 Agustus 2011 (SEMA2011); serta didalam Peraturan Bersama antara Menteri Hukum dan Hak Asasi Manusia RI, Jaksa Agung RI, Kepala Kepolisian Negara RI, Komisi Pemberantasan Korupsi RI, Ketua Lembaga Perlindungan Saksi dan Korban RI tentang Perlindungan bagi Pelapor, Saksi Pelapor dan Saksi Pelaku yang Bekerjasama - tanggal 14 Desember 2011 (PB 2011).

Kelemahan pengaturan yang demikian mengakibatkan pelaksanaan pemberian perlindungan justice collaborator menjadi tidak imperatif atau himbauan saja bagi para penegak hukum, karena SEMA 2011 dan PB 2011 tidak tercantum dalam peraturan perundang-undangan formil pada Pasal 7 UU RI No. 12 Tahun 2011 tentang Pembentukan Peraturan Perundangundangan, selain karena bersifat internal mengikat instansi yang bersangkutan juga didalamnya tidak memuat sanksi, terlebih terhadap keberlakuan SEMA yang merupakan surat dinas belaka.

Dengan demikian sesungguhnya terdapat kekosongan peraturan hukum (leemten in het recht) dalam pengaturan mengenai eksistensi dari justice collaborator meskipun dalam praktik peradilan pidana peran justice collaborator signifikan digunakan dalam pembuktian perkara pidana.

Penggunaan kesaksian justice collaborator disisi lain juga masih diatur secara kabur (vague van normen), perumusan Pasal 10 Ayat (2) UU PSK tidak menjelaskan kriteria keterangan dari justice collaborator yang dapat dijadikan pertimbangan oleh hakim untuk meringankan hukumannya, 
terlebih apabila melihat ketentuan pada Pasal 189 Ayat (3) KUHAP dimana keterangan terdakwa hanya berlaku untuk dirinya sendiri, serta Pendapat Nyoman Serikat Putra Jaya menegaskan kesamaan saksi justice collaborator dengan saksi mahkota yang diatur dalam Pasal 200 RUU KUHAP apabila melihat pengalaman yang lalu dalam Yurisprudensi Perkara Marsinah kesaksian saksi mahkota rentan mengalami penolakan hakim.

Kekosongan dan kekaburan norma hukum dalam pengaturan justice collaborator mengakibatkan pelaksanaan perlindungan hukumnya menjadi kacau, mengingat justice collaborator yang akan bersaksi dipersidangan berada dalam posisi yang riskan atas keselamatan nyawanya, maka diperlukan adanya interpretasi atau penafsiran hukum sebagai salah satu metode penemuan hukum yang memberikan penjelasan terhadap teks undang-undang agar ruang lingkup kaedah dapat ditetapkan sehubungan dengan peristiwa tertentu. Terlepas dari kontroversi terhadapnya, justice collaborator memiliki peran yang strategis bagi pemberantasan korupsi secara tuntas.

Berdasarkan pada uraian latar belakang tersebut diatas, dapat dirumuskan permasalahan yang diangkat dalam tulisan ini yaitu : Apakah telah terdapat pengaturan dan perlindungan hukum bagi Justice Collaborator tindak pidana korupsi menurut hukum positif di Indonesia?

dan Apakah kesaksian seorang justice collaborator memiliki kekuatan nilai pembuktian yang akurat dalam persidangan?

\section{ISI MAKALAH}

\subsection{Metode Penulisan :}

Penulisan makalah ini, menggunakan metode penelitian yuridis normatif dengan jenis pendekatan peraturan perundangundangan dan konseptual terkait dengan masalah yang dibahas. Sumber bahan hukum menggunakan bahan hukum primer, sekunder dan tersier melalui studi dokumen (library research) terhadap bahan hukum yang diperoleh dari peraturan perundangundangan, buku-buku, kamus hukum dan dokumen yang terkait justice collaborator.

\subsection{HASIL DAN PEMBAHASAN}

\subsubsection{Tinjauan Umum tentang Perlindungan Hukum, Justice Collaborator dan Tindak Pidana Korupsi}

Philipus M. Hadjon menyatakan perlindungan Hukum adalah perlindungan akan harkat martabat, serta pengakuan terhadap hak-hak asasi manusia yang dimiliki oleh subyek hukum berdasarkan ketentuan hukum dari kesewenangan. ${ }^{3}$

Konvensi PBB Anti Korupsi Tahun 2003 (United Nation Convention Against Corruption) pada Pasal 37 memberikan istilah yang pemaknaannya sama dengan justice collaborator sebagai "an accused Hadjon,Philipus, M., 1987 , Perlindungan Hukum Bagi Rakyat Indonesia, Bina Ilmu, Surabaya, h. 37. 
person who provides substantial cooperation in the investigation or prosecution" yaitu tersangka/terdakwa yang memberikan kerjasama dalam tingkat penyelidikan atau penuntutan. Konvensi PBB Anti Kejahatan Transnasional yang Terorganisasi (United Nation Convention Against Transnational Organized Crimes 2000) pada Pasal 26 juga mengistilahkan justice collaborator dengan "an accused person who provides substantial cooperation in the investigation or prosecution".

Pengertian di atas pada dasarnya sejalan dengan pengertian menurut Council of Europe Committee of Minister, ${ }^{4}$ bahwa yang dimaksud dengan collaborator of justice adalah Seseorang yang juga berperan sebagai pelaku tindak pidana, atau secara meyakinkan adalah merupakan bagian dari tindak pidana yang dilakukan secara bersama-sama atau kejahatan terorganisir dalam segala bentuknya, atau merupakan bagian dari kejahatan terorganisir, namun yang bersangkutan bersedia untuk bekerjasama dengan aparat penegak hukum untuk memberikan kesaksian mengenai suatu tindak pidana yang dilakukan bersama-sama atau terorganisir, atau mengenai berbagai bentuk tindak pidana yang terkait dengan kejahatan terorganisir maupun kejahatan serius lainnya.

Semendawai, Abdul Haris, Penanganan dan Perlindungan 'Justice Collaborator'dalam Sistem HukumPidana di Indonesia, diakses dari http:// www.elsam.or.id/downloads/1308812895 penanganan_dan_perlindungan_justice_collaborator_.pdf diakses pada Kamis, 19Juni 2014
Istilah tindak pidana merupakan salinan dari istilah "strafbaar feit" yang maknanya telah disamakan, sehingga sama halnya dengan istilah lain seperti peristiwa pidana. Menurut Simons pengertian strafbaarfeit adalah kelakuan (handeling) yang diancam dengan pidana yang bersifat melawan hukum, yang berhubungan dengan kesalahan dan yang dilakukan oleh orang yang mampu bertanggung jawab.

Pengertian atau asal kata korupsi menurut Focema Andreae dalam Andi Hamzah, kata korupsi berasal dari bahasa latin corruptio atau cor-ruptus (Webster Student Dictionary;1960), yang selanjutnya disebutkan bahwa coruptio itu berasal dari kata asal corrumpere, suatu kata dalam bahasa latin yang lebih tua. Dari bahasa latin itulah turun kebanyak bahasa Eropa seperti dalam Bahasa Inggris yaitu corruption, corrupt; dalam Bahasa Perancis yaitu corruption, dan Bahasa Belanda, yaitu corruptie (korruptie), dapat atau patut diduga istilah korupsi berasal dari bahasa Belanda dan menjadi bahasa Indonesia, yaitu "korupsi". 5

Piers Beirne and James Messerchmidt ${ }^{6}$ menjelaskan mengenai empat tipe perbuatan korupsi tersebut, yakni:

1. Political beribery adalah kekuasaan di bidang legislative sebagai badan pembentukundang-undang,yangsecara politis badan tersebut dikendalikan

Andi Hamzah, 2006, Pemberantasan Korupsi Melalui Hukum Pidana Nasional dan Internasional, Rahagrafindo Persada, Jakarta, h.4-6.

6 Ermansjah Djaja, 2010, Meredesain Pengadilan Tindak Pidana Korupsi-Implikasi Putusan Mahkamah Konstitusi Nomor 012-016-019/PPU-IV/2006, Sinar Grafika, Jakarta, h. 18. 
oleh suatu kepentingan karena dana yang dikeluarkan pada masa pemilihan umum sering berhubungan dengan aktifitas perusahaan tertentu yang bertindak sebagai penyandang dana. Dimana individu pengusaha sebagai pemilik perusahaan berharap agar anggota parlemen yang telah diberi dukungan dana pada saat pemilihan umum dan yang kini duduk sebagai anggota parlemen dapat membuat peraturan perundang-undangan yang menguntungkan usaha atau bisnis mereka.

2. Political kickback adalah kegiatan korupsi yang berkaitan dengan system kontrak pekerjaan borongan, antara pejabat pelaksana atau pejabat terkait dengan pengusaha, yang memberikan kesempatan atau peluang untuk mendapatkan banyak uang bagi kedua belah pihak.

3. Election fraud adalah korupsi yang berkaitanlangsung dengan kecurangankecurangandalampelaksananpemilhan umum, baik yang dilakukan oleh calon penguasa/anggota parlemen ataupun oleh lembaga pelaksana pemilihan umum.

4. Corrupt campaign practice adalah korupsi yang berkaitan dengan kegiatan kempanye dengan menggunakan fasilitas Negara dan juga bahkan penggunaan uang Negara oleh calon penguasa yang saat itu memegang kekuasaan.

\subsubsection{Pengaturan dan Perlindungan Hukum bagi Justice Collaborator menurut Hukum Positif di Indonesia}

Negara Indonesia merupakan Negara hukum yang memberikan jaminan perlindungan hukum bagi saksi, tersangka, terdakwa maupun narapidana dalam hukum pidana materiil dan formil Indonesia yang berkonsepkan due process of law. Terkait dengan perlindungan hukum terhadap justice collaborator, Heri Tahir ${ }^{7}$ mengemukakan proses hukum yang adil pada hakikatnya merupakan roh dari sistem peradilan pidana itu sendiri yang ditandai dengan adanya perlindungan terhadap hak-hak tersangka dan terdakwa, dalam hal ini justice collaborator.

Pengaturan mengenai perlindungan saksi masih tersebar dalam beberapa ketentuan peraturan perundang-undangan mengenai saksi yang masih berlaku baik sebelum dan sesudah adanya Konvensi UNCATOC Tahun 2000 dan UNCAC Tahun 2003. Tidak adanya definisi formil mengenai justice collaborator, dimana KUHAP dan UU PSK sama-sama tidak mengatur secara sepsifik mengenai jenis atau pembagian saksi dan pemaknaan justice collaborator, namun kenyataannya dalam praktik hukum pidana telah dikenal sebutan justice collaborator.

Terhadap kekosongan hukum mengenaijustice collaborator yang demikian maka digunakan metode penalaran hukum

Heri Tahir, 2010, Proses Hukum yang Adil Dalam Sistem Peradilan Pidana di Indonesia, cetakan pertama, LaksBang PRESSindo, Yogyakarta., h.7 
Argumentum Per Analogian (Analogi), maka peraturan perundang-undangan yang ruang lingkupnya terlalu sempit akan coba diperluas, dimana peristiwa yang serupa, sejenis atau mirip dengan yang diatur dalam undang-undang akan diperlakukan sama. Beberapa pengaturan yang memuat mengenai perlindungan hukum bagi justice collaborator dalam hukum positif di Indonesia teridentifikasi sebagai berikut:

\section{KUHAP}

KUHAP tidak membagi penggolongan saksi dan derajat perlindungan yang diberikan kepada saksi tersebut, selain itu KUHAP juga tidak signifikan memberikan perlindungan hukum terhadap saksi, namun perlindungan hukum terhadap justice collaborator dengan statusnya sebagai tersangka dan terdakwa telah diakomodir sebagaimana diatur dalam Pasal 50-55, 57-65 KUHAP.

2. UU RI No. 31 Tahun 1999 sebagaimana diubah dan ditambah dengan UU RI No. 20 Tahun 2001 tentang Pemberantasan Tindak Pidana Korupsi (UU Tipikor)

Pasal 41 dan 42 UU Tipikor tidak mengatur secara spesifik perlindungan hukum bagi justice collaborator, hanya terdapat perlindungan terhadap hak dan peran masyarakat dalam upaya pemberantasan tindak pidana korupsi. Apabila ditafsirkan secara kontekstual Justice collaborator sebagaiwargaNegaradananggotamasyarakat berhak untuk memberikan informasi terkait terjadinya tindak pidana korupsi dengan demikian Justice collaborator berhak pula mendapatkan jaminan perlindungan atas informasi yang diberikannya.

\section{UU RI No. 13 Tahun 2006 tentang Perlindungan Saksi dan Korban (UU PSK)}

UU PSK tidak membagi secara spesifik jenis saksi namun justice collaborator terkategori sebagai saksi menurut pasal 1 Ayat (1) UU ini, dan telah diberikan perlindungan sejak tahapan penyelidikan dimulai. Telah diaturdalamUUinibentukperlindunganyang akan diberikan kepada justice collaborator, dan cara pemberian kesaksian tanpa hadir, secara tertulis atau melalui sarana elektronik dengan menuangkannya kedalam Perjanjian Perlindungan LPSK terhadap saksi/korban sesuai ketentuan yang berlaku.

Kelemahan yang nampak dalam UU PSK adalah ambiguitas bunyi Pasal 10 Ayat (2) mengenai penggunaan keterangan saksi justice collaborator dan penamaannya sebagai "saksi yang juga tersangka". Menurut Saldi Isra penamaan tersebut menimbulkan permasalahan dalam penerapannya seperti dalam kasus Susno Duadji, ia yang awalnya sebagai saksi whistle blower yang dibebaskan dari penuntutan pidana oleh Pasal 10 Ayat (1) UU PSK apabila dikemudian hari menjadi tersangka maka perlindungan hukumnya dicabut dan harus dipidana sebagai justice collaborator.

\section{Keputusan Presiden RI No. 174} Tahun 1999 tentang Remisi

Kebijakan hukum di Indonesia, mengharuskan justice collaborator tetap akan dipidana apabila terbukti bersalah, meskipun demikian sesuai dengan ketentuan perundang-undangan yang berlaku, ia tetap memperoleh perlindungan hukum seperti 
keamanan dan pemenuhan atas hak-haknya, termasuk pemberian remisi. Keppres ini masih belum spesifik mengatur pemberian remisi sebagai reward bagi justice collaborator. dan prosedur apa saja yang ia lakukan untuk mendapatkan remisi tersebut.

Berdasarkan ketentuan tersebut, sangat beralasan apabila justice collaborator diberikan reward khusus terkait pemidanaan yang tertuang secara formil peraturan.

\section{Perpres RI No. 55 Tahun 2012 tentang Strategi Nasional Pencegahan Pemberantasan Korupi Jangka Panjang Tahun 2012-2025 dan Jangka Menengah Tahun 2012- 2014}

Sudarto menyatakan penal policy dapat diartikan sebagai usaha mewujudkan peraturan perundang-undangan pidana yang sesuai dengan keadaan dan situasi pada suatu waktu dan untuk masa-masa yang akan datang. Keberadaan Perpres sebagai dokumen yang memuat visi, misi, sasaran, strategi dan fokus kegiatan prioritas pencegahan dan pemberantasan korupsi telah memberikan gambaran kebijakan hukum pidana akan pentingnya pencegahan dan pemberantasan korupsi salah satunya melalui pengaplikasian peran justice collaborator dalam sistem hukum Indonesia, yaitu :

Pertama, Perpres menegaskan bahwa bentuk perlindungan hukum justice collaborator mengarah pada UU RI No. 13 Tahun 2006 Tentang Perlindungan Saksi dan Korban.

Kedua, Pada Bab II Lampiran Perpres dikatakan strategi kebijakan hukum pidana adalah mengharmonisasi penyusunan peraturanperundang-undanganyangtumpang tindih dalam rangka implementasi UNCAC terkait proses penegakan hukum antara lain dengan perlindungan saksi dan pelaku yang bekerjasama (justice collaborator).

Ketiga, Bab IV Lampiran Perpres menyebut piranti anti korupsi dalam mengimplementasikan Stranas Pencegahan dan Pemberantasan Korupsi salah satunya adalah perlindungan bagi whistle blower dan justice collaborator.

Pada Perpres ini penggunaan istilah justice collaborator telah baku dipergunakan, sehingga termuat dalam peraturan perundangundangan formil.

6. PP RI No. 71 Tahun 2000 tentang Tatacara Pelaksanaan Peran serta Masyarakat dan Pemberian Penghargaan dalam Pencegahan dan Pemberantasan Tindak Pidana Korupsi

Pasal 5 PP ini menyebutkan Setiap orang, Organisasi Masyarakat, atau Lembaga Swadaya Masyarakat sebagaimana dimaksud dalam Pasal 3 ayat (1) berhak atas perlindungan hukum baik mengenai status hukum maupun rasa aman. Perlindungan terhadap status hukum diberikan kepada pelapor tindak pidana (whistle blower) saja, sedangkan justice collaborator tidak disinggung secara spesifik. Dengan demikian reward kepada justice collaborator masih diatur secara kabur. Lebih lanjut Pasal 7 PP memberikan penghargaan kepada Setiap orang, Organisasi Masyarakat, Lembaga Swadaya Masyarakat yang telah berjasa 
dalam usaha membantu upaya pencegahan atau pemberantasan tindak pidana korupsi berupa piagam atau premi.

Permasalahan yang mengemuka didalam pengaturan Pasal 5 ayat (2) PP, dimana perlindungan status hukum tidak diberikan apabila dari hasil penyelidikan atau penyidikan terdapat bukti yang cukup yang memperkuat keterlibatan pelapor dalam tindak pidana yang dilaporkan, sehingga ketentuan tersebut dapat mengancam status hukum saksi atau pelapor.

\section{Peraturan Bersama Tahun 2011 (PB 2011)}

PB 2011 menyebut justice collaborator dengan istilah saksi pelaku yang bekerjasama.

Peraturan Bersama Menteri merupakan bentuk tertulis, bersifat pengaturan dan berlaku umum akan tetapi secara kewenangan, Menteri tidak tepat mengeluarkan Peraturan Bersama karena karena tidak ada atribusi ataupun delegasi dari peraturan perundangundangan.

Peraturan Bersama, walaupun demikian tetap digunakan dalam praktik tata Negara mengingat adanya kekosongan hukum khususnya yang mengatur mengenai perlindungan hukum dan perlakuan bagi justice collaborator dalam Pasal 10 Ayat (2) UU PSK.

PB ini mengatur syarat untuk mendapatkan perlindungan sebagai Saksi Pelaku yang Bekerjasama :

“a. Tindak pidana yang akan diungkap merupakan tindak pidana serius dan/ atau terorganisir; b. Memberikan keterangan yang signifikan, relevan dan andal untuk mengungkap suatu tindak pidana serius dan/atau terorganisir;

c. Bukan pelaku utama dalam tindak pidana yang akan diungkapnya;

d. Kesediaan mengembalikan sejumlah aset yang diperolehnya dari tindak pidana yang bersangkutan, hal mana dinyatakan dalam pernyataan tertulis; dan

e. Adanya ancaman yang nyata atau kekhawatiran akan adanya ancaman, tekanan, baik secara fisik maupun psikis terhadap saksi pelaku yang bekerjasama atau keluarganya apabila tindak pidana tersebut diungkap menurut keadaan yang sebenarnya."

PB 2011 menjamin justice collaborator akan memperoleh perlindungan fisik, psikis, dan hukum sebagaimana diatur dalam UU yang berlaku; penanganan secara khusus dalam hal pemisahan tempat penahanan, pemberkasan perkara yang terpisah, penundaan penuntutan, penundaan proses hukum dan memberikan kesaksian didepan persidangan tanpa menunjukkan wajah/ identitasnya; serta pemberian penghargaan dalam hal keringanan tuntutan hukum termasuk hukuman percobaan, pemberian remisi tambahan dan hak narapidana lain.

PB juga mengatur mekanisme/tatacara pengajuan perlindungan justice collaborator melalui rekomendasi penegak hukum dalam setiap tahapan penanganan perkara kepada LPSK. Pemberian perlindungan dapat dibatalkan karena hal-hal tertentu. 
Meskipun cukup komprehensif namun PB 2011 didalamnya tidak memuat sanksi pidana apabila lembaga atau kementerian dan komisi didalamnya tidak menaati prosedur pemberian perlindungan hukum bagi justice collaborator sehingga daya ikat dari pemberlakuan Peraturan Bersama ini masih lemah.

\section{SEMA No. 4 Tahun 2011 (SEMA 2011)}

Permendagri No. 55 Tahun 2010 Pasal 1 butir 43 menjelaskan bahwa Surat Edaran adalah Naskah dinas yang berisi pemberitahuan, penjelasan, dan/atau petunjuk cara melaksanakan hal tertentu yang dianggap penting dan mendesak. SEMA 2011 merupakan surat dinas yang diterbitkan oleh Mahkamah Agung Republik Indonesia tanggal 10 Agustus 2011 untuk diedarkan ke lingkup internal MA, sehingga keberlakuannya pun tidak dapat dipaksakan, dan dikhawatirkan menimbulkan disparitas penerapan hukum kedepannya.

SEMA 2011 menentukan seorang terdakwa dapat dijadikan justice collaborator:

"1. Yang bersangkutan merupakan salah satu pelaku tindak pidana tertentu sebagaimana dimaksud dalam SEMA;

2. Telah mengakui kejahatan yang dilakukannya;

3. Bukan pelaku utama dalam kejahatan tersebut;

4. Memberikan keterangan sebagai saksi didalam proses peradilan."

SEMA menentukan agar putusan bagi justice collaborator dapat diberi keringanan maka Jaksa dalam Surat tuntutannya harus menyatakan terdakwa adalah justice collaborator. Sehingga Hakim dapat menentukan pidana yang akan dijatuhkan yaitu pidana percobaan bersyarat khusus dan/atau menjatuhkan pidana berupa pidana penjara paling ringan diantara terdakwa lainnya yang terbukti bersalah.

Teori kebijakan hukum pidana (penal policy) dan Teori Harmonisasi Hukum tersebut esensinya bersinergi dan berkorelasi dengan makna dan tujuan dari Teori Hukum Progresif dari Satjipto Rahardjo bahwa inti dan makna tujuan Teori Hukum Progresif dimana hukum selalu dituntut untuk progress atau maju dan berwawasan kedepan termasuk manusianya atau hukum untuk manusia bukan sebaliknya manusia untuk diperalat hukum.

Untuk kemajuan perkembangan hukum manusia (dalam hal ini legislator, penegak hukum, pemerintah /eksekutif serta yudikatif) harus memiliki terobosan, dalam mengaplikasikan hukum itu sendiri. Manusia dan produk yang didalamnya menciptakan substansi hukum(peraturan perundang-undangan) harus pula progress dalam mengatasi kekosongan hukum, hal mana yang belum ada agar digagas dan diwujudkan seperti halnya keberadaanjustice collaborator dan apa yang belum lengkap hendaknya direvisi, dikonstruksi aturannya misalnya keberadaan justice collaborator. 


\subsubsection{Kekuatan Pembuktian dari Kesaksian Seorang Justice Collaborator}

Kesamaan konsepsi antara justice collaborator dan saksi mahkota yang menampakkan latar belakang kesamaan hal yang mendasari munculnya peran keduanya yaitu atas kesulitan penegak hukum mencari alat bukti guna mendukung pembuktian perkara korupsi yang dilakukan secara terorganisir/bersama-sama, sehingga seringkali berkas perkara yang ada displitsing jika ingin menggunakan kesaksian kesaksian dari terdakwa lainnya. Pemeriksaan seperti ini dibenarkan oleh Mahkamah Agung RI dengan Putusan MA RI Nomor 66K/Kr/1967 tanggal 25 Oktober 1967.

Keakuratan keterangan saksi yang demikian jika melihat kepada Teori Pembuktian yang dianut sistem peradilan pidana Indonesia dalam pasal 183 KUHAP yaitu Teori Pembuktian berdasarkan UndangUndang secara Negatif (Negatief Wettelijke Bewijstheorie) adalah dapat dipergunakan oleh hakim, guna memperjelas kekaburan norma pada Pasal 10 Ayat (2) UU PSK asalkan memenuhi persyaratan keabsahan alat bukti dan memperoleh keyakinan hakim, sebagaimana ditentukan dalam KUHAP :

- hadir dipersidangan dalammemberikan kesaksian;

- pemberian kesaksian tersebut harus disumpah;

- keterangannya sesuai dengan keterangan saksi lainnya atau alat bukti yang lain;

- keterangannya mengenai peristiwa pidana yang dilihat, didengar dan dialami oleh justice collaborator sendiri dari sumbernya; dan

keterangan saksi tersebut merupakan tambahan disamping minimal alat bukti yang lain guna mengantisipasi ditolaknya keterangan justice collaborator oleh terdakwa.

\section{PENUTUP}

\section{Simpulan}

1. Pengaturan dan Perlindungan Hukum justice collaborator tindak pidana korupsi menurut hukum positif di Indonesia masih terdapat kekosongan norma hukum, selama ini pengaturan perlindungan hukum justice collaborator tergabung dan tersebar didalam beberapa ketentuan perundang-undangan formil tentang saksi dan tindak pidana korupsi, sedangkan peraturan khusus mengenai eksistensi dan perlindungan hukum justice collaborator diatur sebatas pada SEMA Tahun 2011 dan PB Tahun 2011 sehingga perlindungan hukum yang diberikan terhadap justice collaborator belum diberikan secara maksimal dan pelaksanaannya tidak mengikat.

2. Kekuatan pembuktian dari kesaksian seorang justice collaborator dalam persidangan meskipun perumusannya masih kabur didalam Pasal 10 Ayat (2) UU PSK dimana keterangan justice collaborator dapat dijadikan pertimbangan untuk 
meringankan hukumannya oleh hakim, namun dengan menafsirkan norma didalam KUHAP keterangan justice collaborator dapat dijadikan pertimbangan oleh hakim dan akurat sepanjang memenuhi persyaratan guna memperoleh keyakinan hakim, disamping bahwa dengan itikad baik ia harus hadir dipersidangan dengan memberikan kesaksian.

\section{Saran}

1. Hendaknya pengaturan dan perlindungan hukum terhadap justice collaborator tindak pidana korupsi dipertegas termasuk didalamnya diatur mengenai pemberian reward bagi justice collaborator yang berhasil mengungkap tindak pidana korupsi secara signifikan, dalam hal ini Pembentuk Undang-Undang agar mengubah UU RI No. 13 Tahun 2006 tentang Perlindungan Saksi dan Korban secara parsial atau seutuhnya yang menyangkut ketentuan saksi pelaku yang bekerjasama dengan memperhatikan harmonisasi pengaturandalamperaturanperundangundangan lainnya .

2. Hendaknya Pembentuk UndangUndang mempertegas ketentuan mengenai kriteria kesaksian justice collaborator yang dapat menjadi pertimbangan hakim untuk meringankan pidananya kedalam revisi UU RI No. 13 Tahun 2006 tentang Perlindungan Saksi dan Korban .

\section{DAFTAR PUSTAKA}

AndiHamzah, 2006, Pemberantasan Korupsi Melalui Hukum Pidana Nasional dan Internasional, Rahagrafindo Persada, Jakarta

Ermansjah Djaja, 2010, Meredesain Pengadilan Tindak Pidana KorupsiImplikasi Putusan Mahkamah Konstitusi Nomor 012-016-019/PPUIV/2006, Sinar Grafika, Jakarta

Fausto Zuccarelli, 2011, Vice Chief Prosecutor's Office attached to the court of Naples, Italy, Handling and Protecting WitnessesandCollaborators of Justice in Italy, International Seminar and Focus Group Discussion The Protection of Whistleblowers as Justice collaborators, Jakarta, July $19-20^{\text {th }}$

Hadjon,Philipus, M., 1987 , Perlindungan Hukum Bagi Rakyat Indonesia, Bina Ilmu, Surabaya

Heri Tahir, 2010, Proses Hukum yang Adil Dalam Sistem Peradilan Pidana di Indonesia, cetakan pertama, LaksBang PRESSindo, Yogyakarta.

Semendawai, Abdul Haris, Penanganan dan Perlindungan 'Justice Collaborator' dalam Sistem HukumPidana di Indonesia, diakses dari http://www. elsam.or.id/downloads/1308812895 penanganan_dan_perlindungan justice_collaborator_pdf diakses pada Kamis, 19Juni 2014 